\title{
In vitro genotoxic study reinforces the use of titanium- 35niobium alloy in biomedical implants
}

Received: 12 March, 2020

Accepted: 01 April, 2020

Published: 02 April, 2020

*Corresponding author: Isabel Chaves Silva Carvalho, Av. Shishima Hifumi, 2911-Urbanova, São José dos Campos-São Paulo -Brazil, ZIP-Code:12244-000; Tel: 5512 39471138; E-mail: belcscarvalho@gmail.com Keywords: Biomaterial; Genotoxicity; Damage; DNA; Cells; Biomedical

https://www.peertechz.com

\section{Check for updates}

\section{Dennia Perez de Andrade ${ }^{1,2}$, Isabel Chaves Silva \\ Carvalho ${ }^{2,3 *}$, Bruno Henrique Godoi ${ }^{2}$, Newton Soares da Silva ${ }^{3}$, Carlos Alberto Alves Cairo ${ }^{4}$, Cristina Pacheco Soares $^{2}$ and Yasmin Rodarte Carvalho ${ }^{1}$}

\author{
${ }^{1}$ Institute of Science and Technology, UNESP-Univ Estadual Paulista, Department of Biosciences and \\ Oral Diagnosis, Sao Jose dos Campos, Sao Paulo, CEP 12245-000, Brazil \\ ${ }^{2}$ Institute of Research and Development-IP\&D, Universidade do Vale do Paraíba-UNIVAP, Laboratory \\ Dynamics of Cellular Compartments, Sao Jose dos Campos, Sao Paulo, CEP 12244-000,Brazil \\ ${ }^{3}$ Institute of Research and Development-IP\&D, Universidade do Vale do Paraíba-UNIVAP, Laboratory of \\ Cell Biology and Tissue, Sao Jose dos Campos, Sao Paulo, CEP 12244-000, Brazil \\ ${ }^{4}$ Division of Materials, Air and Space Institute, CTA, Praça Mal. do Ar Eduardo Gomes, 14, São José \\ dos Campos, Sao Paulo, CEP 12228-615, Brazil
}

\begin{abstract}
Titanium-Niobium (TiNb) alloys have been considered a good alternative for several biomedical applications. Titanium-35niobium (Ti-35Nb) alloy has an excellent biological profile and shows a great potential for biomedical application in both the orthopedic and dentistry fields. In this study, the comet assay and micronucleus assays, sensitive assays for DNA damage, were used to evaluate potential genotoxicity in model cell type exposed to Ti-35Nb alloy and pure titanium (Ti pure). Human osteosarcoma cells (MG63) were exposed to Ti-35Nb and Ti pure extracts and DNA damage assessed at $24 \mathrm{~h}, 48 \mathrm{~h}$, and $72 \mathrm{~h}$. The assays, comet and micronucleus, showed that Ti-35Nb alloy did not cause damage to the cells DNA. Our results demonstrated that Ti-35Nb alloy does not present genotoxicity, reinforcing that this alloy is a promising material and constitutes an alternative in the substitution to the materials currently used in orthopedics and in dentistry.

\section{Impact Statement}

The applications of titanium based alloys are widely used as orthopedic implants due to their excellent combination of mechanical properties, corrosion resistance and outstanding biocompatibility. Recently studies have been demonstrated titanium-niobium alloys do not present cytotoxicity, exhibit corrosion resistance similar or superior to titanium and have elastic modulus significantly lower than other titanium alloys. These characteristics make these materials an alternative for several biomedical applications, mainly implants. Previous studies demonstrated that Ti-35Nb alloy exhibits the closest elastic modulus of bone, and have good performance in key parameters of osteogenesis, which means that this alloy has an excellent biological profile and shows a great potential for biomedical application. In the present study it was demonstrated that Ti-35Nb alloy did not present DNA damage. Thus, these results consolidate this alloy has a promising material to substitution to the materials currently used in orthopedics and in dentistry, with absence of cytotoxity and genotoxity.
\end{abstract}

\section{Introduction}

About 70 to $80 \%$ of biomedical implants are made of metallic materials, and this demand has grown over the years, due to the increase in life expectancy of the population. Even with these numbers, biological and mechanical properties of metallic biomaterials are not ideal, requiring improvements [1]. 
Titanium-Niobium (TiNb) alloys have characteristics that make these materials an alternative for several biomedical applications, mainly implants [2-4]. According to experimental studies, these alloys do not present cytotoxicity, exhibit corrosion resistance similar or superior to Titanium (Ti) and have elastic modulus significantly lower than other titanium alloys [3-11].

The titanium-35niobium (Ti-35Nb) is a binary alloy that was developed by our research group and its main characteristic is to exhibit the closest elastic modulus of bone (80.7 GPa) [5]. In previous study it was demonstrated that $\mathrm{Ti}-35 \mathrm{Nb}$ alloy has good performance in key parameters of osteogenesis in rat calvaria-derived cell cultures [4]. In another study it was showed the molecular mechanisms of interaction between human osteoblasts and the Ti-35Nb alloy follow the principal osseointegration routes of commercially pure titanium, and the expression of key markers of cell adhesion and differentiation indicate that the induction of bone matrix synthesis was similar for $\mathrm{Ti}-35 \mathrm{Nb}$ alloy and commercially pure titanium [12]. Additionally, recent in vitro and in vivo studies present evaluations of powder metallurgy-processed porous samples composed by different titanium alloys and pure $\mathrm{Ti}$, aiming to show their potential for biomedical applications. The results showed that $\mathrm{Ti}-35 \mathrm{Nb}$ alloy have better results than commercially pure titanium and Ti-6 Aluminium-4 Vanadium alloy, the most common materials implants composition, in gene expression and cytokines analysis [13-15]. These results demonstrate that $\mathrm{Ti}-35 \mathrm{Nb}$ alloy has an excellent biological profile and shows a great potential for biomedical application in both the orthopedic and dentistry fields.

However, the biological properties of new biomaterials must be studied to fully explore potential side effects, and a very important parameter had been neglected by studies evaluating the biological properties of new materials, which is the genotoxic potential of biomaterials. The literature describes several studies that aimed to determine the biomaterials cytotoxicity, but few recent studies have emphasized the importance of evaluating the biomaterials genotoxicity $[4,6,7,16-24]$.

Genotoxic agents can be defined functionally as having the ability to alter DNA replication and genetic transmission. The major endpoints of short-term genotoxicity assays include DNA damage, point mutations, and chromosomal aberrations [25]. Thus, genotoxicity describes the capacity of an agent that damages the genetic information in a cell, causing mutations.

The biomaterials interact with the body, consequently, it is very important to evaluate the mutagenic potential of medical biomaterials in the final form. To establish the Ti-35Nb alloy as a biomedical material it is important to evaluate the possibility of this material being genotoxic or not to the organism. Thus, the aim of this study was to examine the genotoxicity of $\mathrm{Ti}-$ $35 \mathrm{Nb}$ alloy in vitro using the comet and micronucleus assays. Human osteosarcoma cells (MG63) were used, a type of model cell types commonly used in biomaterials research. The comet and micronucleus assays were performed in $\mathrm{Ti}-35 \mathrm{Nb}$ alloy extracts.

\section{Materials and methods}

\section{Samples}

Dense and porous $\mathrm{Ti}$ and $\mathrm{Ti}-35 \mathrm{Nb}$ samples were prepared using Ti powders with purity $\mathrm{C} 99.5 \%$ and particle size $8 \mu \mathrm{m}$, which were formed by hydrogenation and dehydrogenation, the samples were prepared by powder metallurgy, developed at the Materials Division of the Aeronautics and Space Institute of the General Command of Aerospace Technology, São José dos Campos, São Paulo, Brazil. Interconnected pores were obtained in samples of $\mathrm{Ti}$ and $\mathrm{Ti}-35 \mathrm{Nb}$ alloy using a mixed powder with an organic additive (urea), with particles ranging from 177 to $250 \mu \mathrm{m}$ used as space holders.

Dense and porous samples with the test alloy (Ti-35Nb) and pure titanium (pure titanium grade 2 ) were manufactured in the form of $12 \mathrm{~mm}$ diameter disks by $2 \mathrm{~mm}$ high. The procedures of samples manufacture were described and presented in a previous study by our research group in Andrade, et al. [4]. and the Ti-35NB alloy was developed previously by Santos, et al. [5]. Four types of samples were prepared: a) Dense Ti pure; b) Porous Ti pure; c) Dense Ti-35Nb alloy; and d) Porous Ti-35Nb alloy. All the samples were sterilized by Gamma radiation at 20 kGy (Embrarad, Empresa Brasileira de Radiações Ltda, Cotia, SP, Brazil) before the cell assay.

The Ti pure groups (Dense Ti pure and Porous Ti pure) were used to compare with a control group, since this material has been widely used in implants. The dense and porous samples were used in order to verify if the material porosity would influence the materials genotoxicity.

\section{Preparation of sample extracts}

In the present study the genotoxicity of the $\mathrm{Ti}-35 \mathrm{Nb}$ alloy was evaluated by the indirect contact of the samples extracts with the cells, as recommended by ISO 10993-5:2009 directions [26]. This methodology was chosen because direct contact with the sample did not allow sufficient numbers of cells for the comet and micronucleus assays. Porous samples allow the cells interiorization favoring an osseointegration, but they make it difficult to remove the cells for the cell assays due to differences in the surface depth of the samples, which have pores of several sizes and shapes, as demonstrated by Andrade, et al. [4]. by Scanning Electron Microscopy (SEM).

The samples extracts were obtained following the EN ISO 10993-5:2009 directions [26]. Briefly, 2 samples disks by group (7 $\mathrm{g}$ of samples-this quantity of sample was chosen according to EN ISO 10993-5:2009 regulations for the extracts preparation) were put in $20 \mathrm{ml}$ of culture medium Dulbecco's Modified Eagle Medium (DMEM) (Gibco, Grand Island, NY, USA) [26]. The flasks were then incubated at $37^{\circ} \mathrm{C}$ in a humidified $5 \% \mathrm{CO} 2$ for 7 days under stirring at $75 \mathrm{rpm}$ (Cientec CT-712R). Then, the samples were removed from the flasks and the different sample extracts were supplemented with $10 \%$ fetal bovine serum (FBS) (Gibco) and 1\% antibiotic-antimycotic (Gibco).

\section{Cell culture}

Human osteosarcoma cells (MG63 line, Banco de Células 
do Rio de Janeiro, Duque de Caxias, RJ, Brazil) were grown as a monolayer culture in $25-\mathrm{cm}^{2}$ flasks containing DMEM (Gibco) supplemented with $10 \%$ FBS (Gibco) and $1 \%$ of antibiotic-antimycotic (Gibco) until confluent. The cells were cultured at $37{ }^{\circ} \mathrm{C}, 95 \%$ humidity and $5 \% \mathrm{CO}$. The culture medium was changed every 2-3 days. Culture progression was evaluated by phase contrast microscopy (Inverted Microscope OLYMPUS CK40). When the cells reached approximately $80 \%$ of confluence, they were detached by a mixture of trypsin/ EDTA (0.25\%) (Gibco) at $37^{\circ} \mathrm{C}$ for 3 minutes and seeded in 24well polystyrene plates at $2 \times 10^{4}$ cells/well in $500 \mu \mathrm{L}$ of culture medium according to the experimental group. The control group of the cells were seeded in 24-well polystyrene plates at $2 \times 10^{4}$ cells/well in 500 LL of DMEM (Gibco) supplemented with $10 \%$ FBS (Gibco) and 1\% of antibiotic-antimycotic (Gibco). The cells were seeded in 24 -well polystyrene plates at $2 \times 10^{4}$ cells/well in $500 \mu \mathrm{L}$ of respectively sample extracts for Dense $\mathrm{Ti}$ pure, Porous Ti pure, Dense Ti-35Nb alloy, and Porous Ti-35Nb alloy, supplemented with 10\% FBS (Gibco) and 1\% antibioticantimycotic (Gibco).

Three wells were seeded from each group and all the assays were performed in triplicate ( $\mathrm{n}=9$ well/ group).

\section{Comet assay}

The comet assay protocol was performed by Carvalho, et al. [27]. Cells were cultured for $24 \mathrm{~h}, 48 \mathrm{~h}$ and $72 \mathrm{~h}$ in 24 -well polystyrene plates with cell density of $2 \mathrm{X}^{4} \mathrm{O}^{4}$ with their respective sample extract. After each period, 200ul of trypsin/0.25\% EDTA (Gibco) was added to each well of the plate for 3 min to detach the cells. After centrifugation (3000 rpm/5 min), each group of cells was resuspended in $200 \mu$ l of $0.5 \%$ low-melting point agarose $\left(37^{\circ} \mathrm{C}\right)$ (Gibco) and transferred to slides recently prepared with $1.5 \%$ agarose $\left(60^{\circ} \mathrm{C}\right)$ (Gibco). The slides were immersed in freshly prepared cold $\left(4^{\circ} \mathrm{C}\right)$ lysis solution $(\mathrm{NaCl}$ 2.5 M, EDTA 100mM, Tris $10 \mathrm{mM} / 1 \%$ Triton X-100, 10\% DMSO, $\mathrm{ph}=7.65$ ) and kept at $4{ }^{\circ} \mathrm{C}$ for $1 \mathrm{~h}$. The prepared slides were placed in a horizontal electrophoresis cube, which was then filled up with freshly made alkaline buffer at $4^{\circ} \mathrm{C}(300 \mathrm{mM} \mathrm{NaOH}$ and 1 mM EDTA, pH 13). Electrophoresis was performed at 300 $\mathrm{mA}$ and $25 \mathrm{~V}$ for $30 \mathrm{~min}$. The slides were removed, placed in horizontal position and washed three times ( $5 \mathrm{~min}$ each) with $0.4 \mathrm{M}$ TRIS - $\mathrm{HCl}, \mathrm{pH}$ 7.5. A $30 \mu \mathrm{l}$ volume of ethidium bromide $(20 \mu \mathrm{g} / \mathrm{mL}$ ) was added to stain the slides, and the readings were immediately taken under a Epifluorescence microscope (Leica Epifluorescence Microscope DMIB with camera to capture pictures model Leica DFC310FX) at $200 \mathrm{x}$ magnification. For this test, three slides were prepared per well by each group. Ten (10) randomly selected fields per slides were photographed and analysis was performed in 250 randomly selected cells per group. The images were analyzed in the OpenComet analysis software program, and statistically analyzed by the Graphpad Prism 6.0 software program (GraphPad Inc., La Jolla, CA, USA).

\section{Micronucleus assay}

The micronucleus assay protocol was performed by Carvalho, et al. [27]. Cells were cultured for $24 \mathrm{~h}, 48 \mathrm{~h}$ and $72 \mathrm{~h}$ in
24 -well polystyrene plates with cell density of $2 \times 10^{4}$ with their respective sample extract. After each period, the cells were washed twice with Phosphate-Buffered Saline (PBS) and fixed in $4 \%$ paraformaldehyde in phosphate buffer for $10 \mathrm{~min}$ at room temperature. Then the cells were washed again with PBS and incubated with $200 \mu \mathrm{L}$ DAPI (4',6-Diamino-2-Phenylindole, Sigma/Aldrich, St. Louis, USA) in $300 \mathrm{nM}$ phosphate buffer for $10 \mathrm{~min}$ at room temperature. The number of cells with micronuclei was counted with the aid of a fluorescence microscope (Leica Fluorescence Microscope DMIL with camera to capture pictures model Leica DFC310FX) and software Leica Application Suite V3 (400x magnification) in 10 different fields of each well, a total of 30 fields per experimental group. The micronuclei frequency was calculated as the number of cells with micronucleus per 1000 cells per experimental group. The analyses were carried out by one of the co-authors (B.H.G.), who was blind to identification. The criteria used to identify micronuclei were those defined by Tikenko-Holand [28]. Statistical analysis was performed with the Graphpad Prism 6.0 software program (GraphPad Inc., La Jolla, CA, USA).

\section{Statistical analysis}

The data are not normally distributed (KolmogorovSmirnov test) and statistical analysis was performed by using Kruskal-Wallis with Dunn's multiple comparisons posttest in GraphPad Prism 6.0 software (GraphPad Inc., La Jolla, CA). No statistical adjustment was applied to the samples. The comet assay data were expressed as median with interquartile range values for 250 cells analyzed per experimental group. The micronucleus assay data were expressed as mean and standard deviation (SD) for 1000 cells analyzed per experimental group. Statistical significance was set at 0.05 .

\section{Results}

\section{Comet assay}

The percentage of DNA in the comet tail was not significantly different among the groups in $24 \mathrm{~h}(\mathrm{p}=0.6642)$, $48 \mathrm{~h}(\mathrm{p}=0.6281)$ and $72 \mathrm{~h}(\mathrm{p}=0.4986)$ (Figure $1 \mathrm{~A})$. Additionally, when compared among the periods of $24 \mathrm{~h}, 48 \mathrm{~h}$ and $72 \mathrm{~h}$ the percentage of DNA in the comet tail was statistically equal for all groups (Control group $p=0.6297$; Dense Ti pure $p=0.2713$; Porous Ti pure $\mathrm{p}=0.6249$; Dense $\mathrm{Ti}-35 \mathrm{Nb}$ alloy $\mathrm{p}=0.3390$; and Porous $\mathrm{Ti}-35 \mathrm{Nb}$ alloy $\mathrm{p}=0.4823$ ) (Figure $1 \mathrm{~B}$ ). Figure 2 shows some examples of cells submitted to electrophoresis for DNA fragmentation assessment before (A) and after analysis (B) in the OpenComet software.

\section{Micronucleus assay}

The micronucleus frequency did not show significant difference among groups at $24 \mathrm{~h}(\mathrm{p}=0.3976), 48 \mathrm{~h}(\mathrm{p}>0.9999)$ and $72 \mathrm{~h}(\mathrm{p}=0.2762)$ (Figure $2 \mathrm{~A})$. Intra-group comparison of the $24 \mathrm{~h}, 48 \mathrm{~h}$ and $72 \mathrm{~h}$ periods (Figure $2 \mathrm{~B}$ ) showed that the number of micronucleus in most groups was not significantly different (Control $\mathrm{p}=0.2500$; Dense Ti pure $\mathrm{p}=0.1429$; Porous Ti pure $\mathrm{p}=0.1643$; Porous $\mathrm{Ti}-35 \mathrm{Nb}$ alloy $\mathrm{p}=0.3571$ ), however the Dense $\mathrm{Ti}-35 \mathrm{Nb}$ alloy presented significant difference 
$(p=0.0357)$. Figure 3 shows cells nucleus labeled with DAPI. All groups (Control, Dense Ti pure, Porous Ti pure, Dense Ti-35Nb alloy, and Porous Ti-35Nb alloy) presented a large number of cells in the evaluated periods ( $24 \mathrm{~h}, 48 \mathrm{~h}$ and $72 \mathrm{~h}$ ).

\section{Discussion}

$\mathrm{Ti}$ alloys have been studied extensively as an alternative for several biomedical applications, mainly implants $[16,17]$. However, the biomaterials implantation and their duration in the human body have increased steadily, thus, it is necessary to study their long-term effects. One of the most striking issues is the biomaterial potential to cause cancer, a concern dealt with in the medical devices regulation (ISO 10993-3) [22].

Previous studies showed that $\mathrm{Ti}-35 \mathrm{Nb}$ alloy was not cytotoxic and presented an excellent biological profile, similar to that of titanium, and is a promising material in the substitution of the materials currently used for the orthopedic and dentistry implants $[4,12,13]$.

Nevertheless, in order to fully understand risks associated with their clinical application, potential side effects should be evaluated. In this study, DNA strand breaks and levels
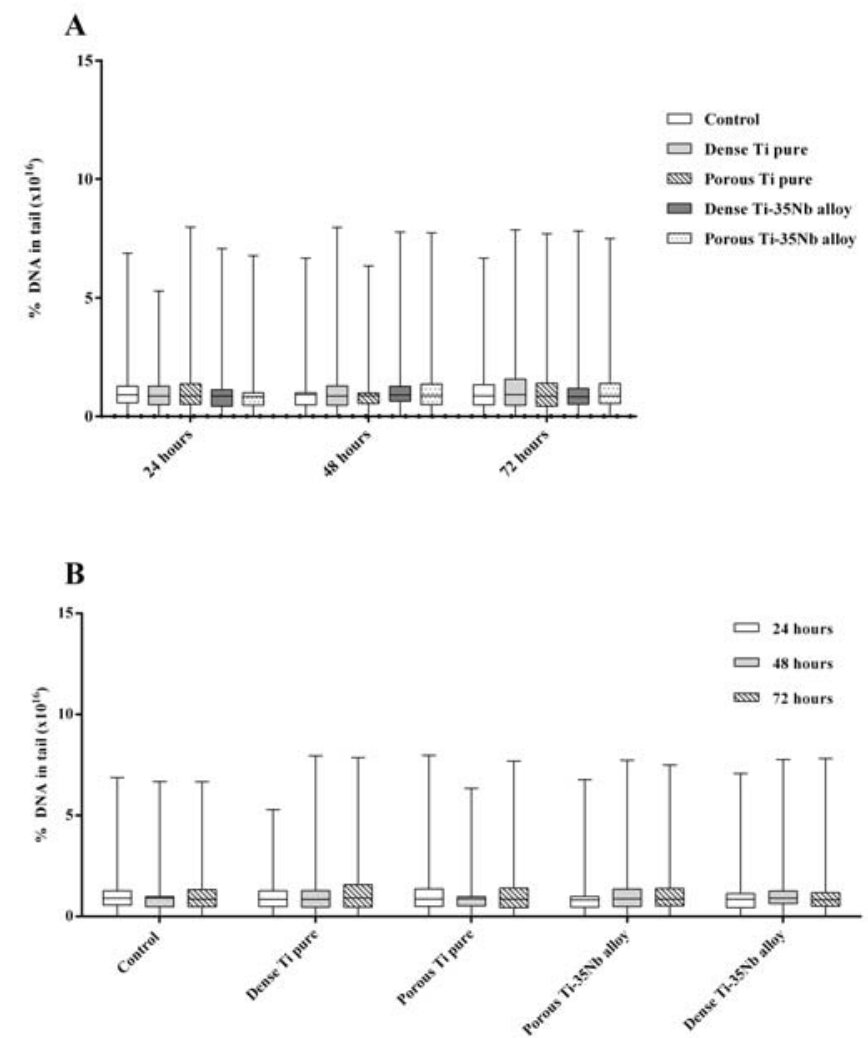

Figure 1: Ti-35Nb alloy does not exhibit significant DNA damage as determined from the analysis of percentage of DNA in comet tail. Graphs showing the median with interquartile range values of percentage of DNA in comet tail $\left(x 10^{16}\right)$. (A) The percentage of DNA in the comet tail was not significantly different among the groups in $24 \mathrm{~h}(\mathrm{p}=0.6642), 48 \mathrm{~h}(\mathrm{p}=0.6281)$ and $72 \mathrm{~h}(\mathrm{p}=0.4986)$. (B) Intra-group comparison of the $24 \mathrm{~h}, 48 \mathrm{~h}$ and $72 \mathrm{~h}$ periods showed that the percentage of DNA in the comet tail was statistically equal for all groups (Control group $p=0.6297$; Dense Ti pure $p=$ 0.2713 ; Porous Ti pure $p=0.6249$; Dense Ti-35Nb alloy $p=0.3390$; and Porous Ti$35 \mathrm{Nb}$ alloy $p=0.4823$ ). Statistical significance with $p<0.05$ by using Kruskal-Wallis test with Dunn's multiple comparisons posttest ( $n=9$ per each group).
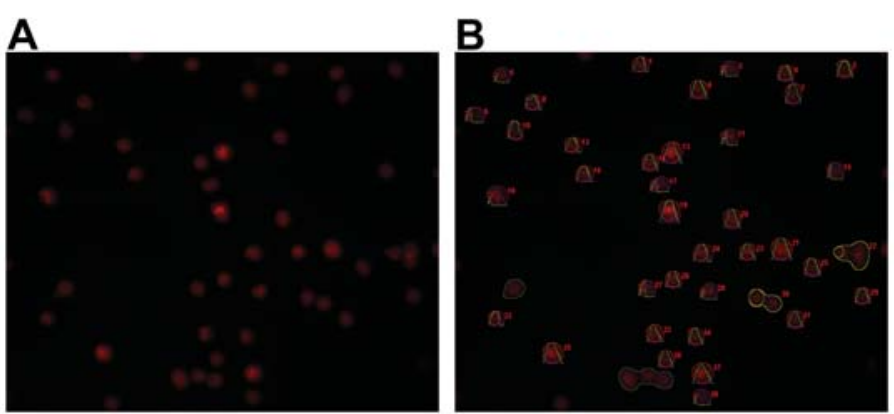

Figure 2: Representative photomicrographs of the cells submitted to electrophoresis for DNA fragmentation assessment observed by epifluorescence microscope; original magnification 200x. (A) Pre analysis and (B) post analysis of OpenComet software.
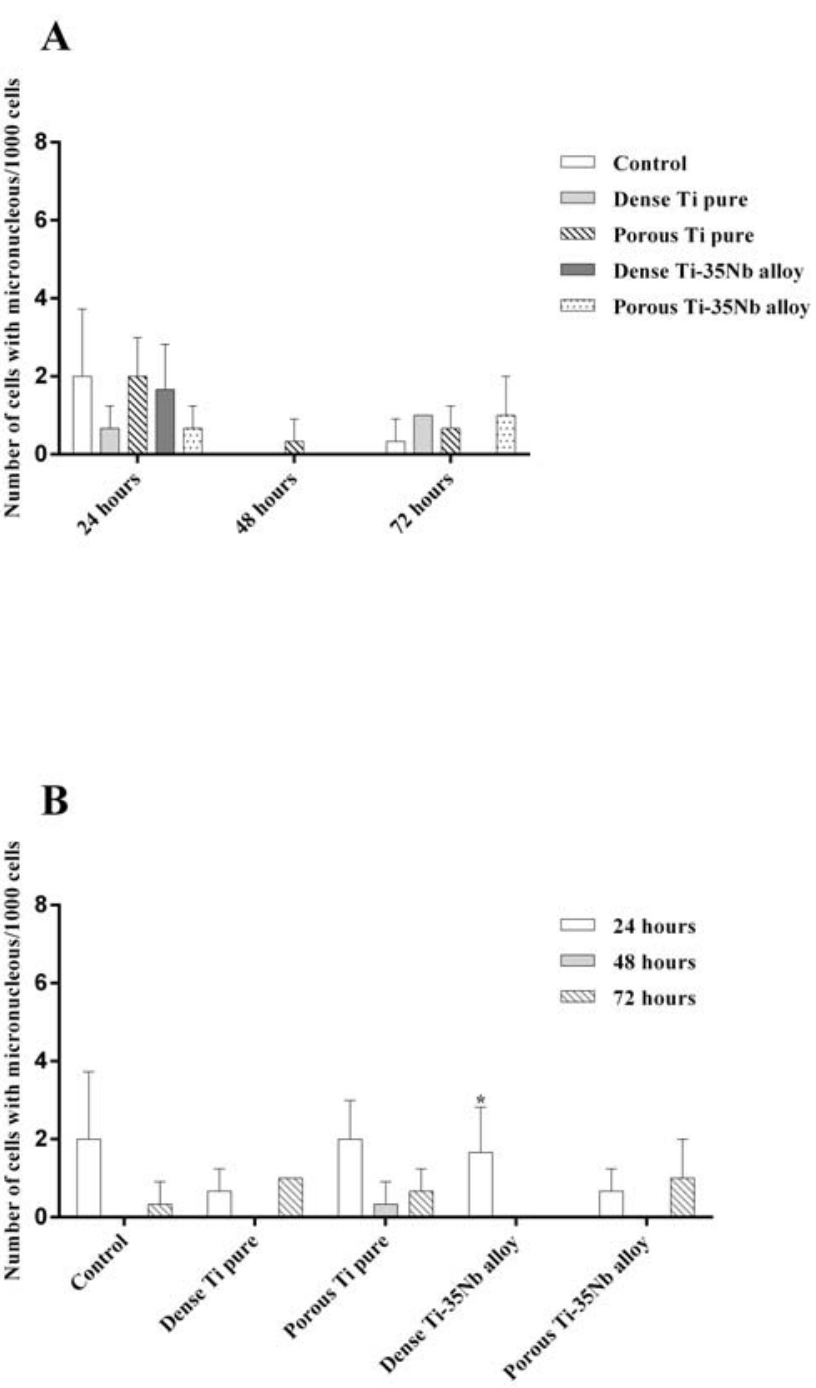

Figure 3: Ti-35Nb alloy does not exhibit significant micronucleus formation as determined from analysis of micronucleus frequency. Graphs showing the average \pm standard deviation of the number of cells with micronucleus. The micronuclei frequency was calculated as the number of cells with micronucleus per 1000 cells per experimental group. (A) The micronucleus frequency did not significant difference among groups at $24 h(p=0.3976), 48 h(p>0.9999)$ and $72 h(p=0.2762)$. (B) Intra-group comparison of the $24 \mathrm{~h}, 48 \mathrm{~h}$ and $72 \mathrm{~h}$ periods showed that the number of micronucleus in most groups was not significantly different (Control $p=0.2500$; Dense Ti pure $p=0.1429$; Porous Ti pure $p=0.1643$; Porous Ti-35Nb alloy $p=0.3571$ ), however the Dense Ti-35Nb alloy presented significant difference $(p=0.0357)$. Statistical significance with $p<0.05$ by using Kruskal-Wallis test with Dunn's multiple comparisons posttest ( $\mathrm{n}=9$ per each group).

Citation: De Andrade DP, Silva Carvalho IC, Godoi BH, Da Silva NS, Soares CP, et al. (2020) In vitro genotoxic study reinforces the use of titanium-35niobium alloy in biomedical implants. Int J Oral Craniofac Sci 6(1): 008-015. DOI: https://dx.doi.org/10.17352/2455-4634.000044 


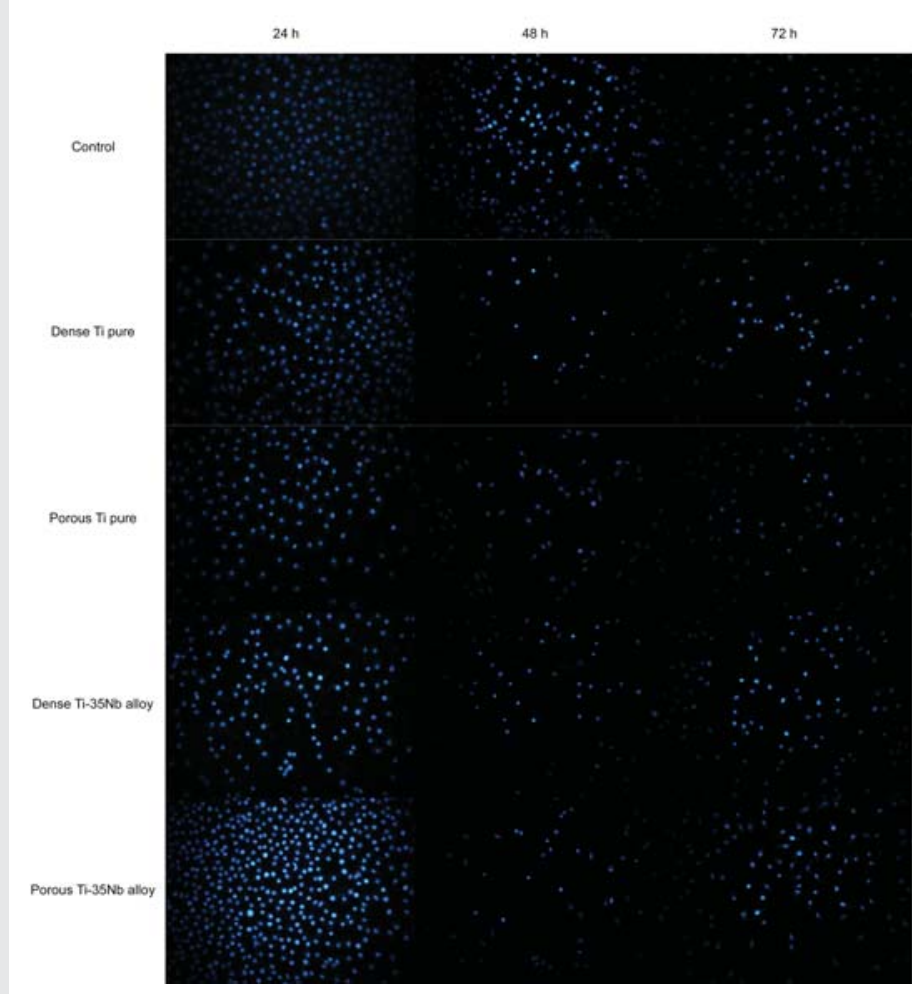

Figure 4: Representative photomicrographs showing the cells nucleus labeled with DAPI (40,6-diamino-2-phenylindole) observed by epifluorescence microscope; original magnification 200x. All groups (Control, Dense Ti pure, Porous Ti pure, Dense Ti-35Nb alloy, and Porous Ti-35Nb alloy) presented a large number of cells in the three evaluated periods ( $24 \mathrm{~h}, 48 \mathrm{~h}$ and $72 \mathrm{~h}$ ).

of unrepaired cellular DNA damage were measured using two simple and reproducible techniques, the comet and micronucleus assay, and the results showed that $\mathrm{Ti}-35 \mathrm{Nb}$ alloy did not present genotoxicity, confirming the great potential of use of this alloy.

The comet assay, also known as single-cell gel electrophoresis (SCGE), is a standard test in the battery of tests used to assess of novel pharmaceuticals or other chemicals [30]. Additionally, according to ISO 10993, an international standard, all materials that will be in contact with mucous, bone, or dentinal tissue if the contact exceeds 30 days, as well as all implantable devices if the contact exceeds $24 \mathrm{~h}$, must undergo genotoxicity testing. Therefore, this technique has been extensively used in assessing genotoxic effects in cells exposed to various toxicants, including the evaluation of the toxicity potential to biomaterials $[19,20,24,26,27,31-34]$.

The comet assay is an efficient, sensitive and rapid method for measuring DNA damages in individual's cells of any type [25,35-38]. This method detects strand breaks, alkali-labile sites, DNA cross-linking, and incomplete excision repair sites and these DNA damages can be analyzed manually by the authors, classifying the size of the comet tail in five classes resulting in a single DNA damage score for each individual cell, or by an automated comet assay image analysis tool [25,35,3942]. Many automated comet assay image analysis tools have been developed and used in studies $[27,37,43]$. These automated tools are more accurate, less prone to human bias and faster than manual analysis, thus, the OpenComet software was used $[37,43]$.
The results of this study revealed that $\mathrm{Ti}-35 \mathrm{Nb}$ alloy, as well as Ti pure, a biomaterial already used in implants, did not cause damage to the cells DNA compared with the Control group. Moreover, it was found that there was no statistical difference among the groups $\mathrm{Ti}-35 \mathrm{Nb}$ dense and porous when compared with the Control group. In the same way, there was no statistical difference among the groups Dense Ti pure and Porous Ti when compared with the Control group, showing that the surface topography of the material also did not influence in the genotoxicity. It means that, although the pores formation on the implant surface significantly increases the area of bone-implant contact due to bone growth in the interior of the pores (bone ingrowth), resulting in the acceleration of osseointegration, the surface topography did not influence in the genotoxicity $[44,45]$.

Micronuclei originate from acentric chromosome fragments that are caused by DNA strand breaks and also by chromosome malsegregation events during the cell cycle interphase. Thus, the micronucleus assay is a method for measuring spontaneous and induced chromosomal damage and separation errors, therefore, this technique can be used to detect chromosomal mutations, clastogenicity, and aneugenicity $[46,47]$.

Several studies have used this method to detect genotoxicity, including in biomaterials $[27,41,48-55,56,57]$. Our results of the micronucleus assay corroborate with the results of the comet assay, which means, they demonstrated that the Ti-35Nb alloy, as well as Ti pure, were not genotoxic, and the material surface topography also did not influence in the genotoxicity. However, in intra-group comparison of the $24 \mathrm{~h}, 48 \mathrm{~h}$ and $72 \mathrm{~h}$ periods showed that the number of micronucleus in the Dense $\mathrm{Ti}-35 \mathrm{Nb}$ alloy presented significant statistical difference $(\mathrm{p}=0.0357)$. This difference occurred because in $24 \mathrm{~h}$ the Ti-35Nb alloy presented micronuclei, but in the other periods $(48 \mathrm{~h}$ and 72 h) the presence of micronuclei was not observed. However, this statistical difference does not mean that this alloy is genotoxic, since when the frequency of micronuclei was compared among the groups there was no statistical difference.

It is important to highlight that the adoption of the cells analysis protocol in the serial monitoring periods of 24,48 and 72 hours makes the data cross-check more robust to evaluate the material genotoxic action. According to ISO / EN109935 [26], for the cytotoxicity test, it is recommended 24 hours of biomaterial exposure, which means that one cell cycle is enough for cell viability to be expressed. A eukaryotic cell has a cell cycle of approximately 24 hours [58]. Thus, in the present study the cells exposed to material extracts were not the same at the end of the 72 hour analysis. Therefore, the evaluation of three distinct cell cycles (24, 48 and 72 hours) demonstrates cell survival in successive generations. This can be considered a long term evaluation.

The immortalized osteoblast cell lineage (MG63) studied here has been used as model cells in biomaterials evaluation [59-61]. This cell type was chosen because of its reproducibility capabilities, and because the relationship of osteoblasts with the bone repair process in tissues makes it ideal for vitro assays researching new implants materials. 
Biocompatibility of a material is closely related to cell behavior in contact with the material. Osseointegration between a biomaterial and bone is dependent on cell adhesion in the material, and for adequate adhesion it is necessary that the biomaterial be not cytotoxic to the cells, as demonstrated in our previous studies $[4,12,13]$. In the present study, the comet and micronucleus assays showed no DNA damage. In view of the observed results, the Ti-35Nb alloy does not present genotoxicity, reinforcing that this alloy is a promising material and constitutes an alternative in the substitution of currently used Titanium and/or Titanium alloys in dentistry and orthopedics.

\section{Author contributions statement}

All authors participated in the design, studies interpretation and data analysis and the manuscript review; DPA, ICSC, and BHG conducted the experiments, NSS and CPS supplied all reagents for the experiments, CAAC supplied the samples, and all authors participated in the manuscript writing.

\section{Declaration of conflict of Interest statement}

The authors declared no potential conflicts of interests concerning the research, authorship, and/or publication of article.

\section{Funding statement}

This work was supported by FAPESP (Fundação de Amparo à Pesquisa do Estado de São Paulo - The State of São Paulo Research Foundation) [grant number 2013/20054-8].

\section{References}

1. Niinomi M, Nakai M, Hieda J (2012) Development of new metallic alloys for biomedical applications. Acta Biomater. Acta Materialia Inc 8: 3888-3903. Link: https://bit.ly/2yn33Nv

2. Li Y, Wong C, Xiong J, Hodgson P, Wen C (2010) Cytotoxicity of Titanium and Titanium Alloying Elements. J Dent Res 89: 493-497. Link: https://bit.ly/3dKEjyz

3. Xu J, Weng X-J, Wang X, Huang J-Z, Zhang C, et al. (2013) Potential Use of Porous Titanium-Niobium Alloy in Orthopedic Implants: Preparation and Experimental Study of Its Biocompatibility In Vitro. Zheng J, editor. PLoS One 8: e79289. Link: https://bit.ly/2URP750

4. de Andrade DP, de Vasconcellos LMR, Carvalho ICS, Forte LF de BP, de Souza Santos EL, et al. (2015) Titanium-35niobium alloy as a potential material for biomedical implants: In vitro study. Mater Sci Eng C. Elsevier BV. 56: 538-544. Link: https://bit.ly/2w5Nau8

5. Santos DR, Pereira MS, Cairo CAA, Graça MLA, Henriques VAR (2008) Isochronal sintering of the blended elemental Ti-35Nb alloy. Mater Sci Eng A 472: 193-197. Link: https://bit.ly/2w5NfOs

6. Wang X, Li Y, Xiong J, Hodgson PD, Wen C (2009) Porous TiNbZr alloy scaffolds for biomedical applications. Acta Biomater. Acta Materialia Inc 5 : 3616-3624. Link: https://bit.ly/39B0532

7. McMahon RE, Ma J, Verkhoturov S V, Munoz-Pinto D, Karaman I, et al. (2012) A comparative study of the cytotoxicity and corrosion resistance of nickeltitanium and titanium-niobium shape memory alloys. Acta Biomater 8: 28632870. Link: https://bit.ly/3dKEDxH

8. Godley R, Starosvetsky D, Gotman I (2006) Corrosion behavior of a low modulus $\beta-\mathrm{Ti}-45 \% \mathrm{Nb}$ alloy for use in medical implants. J Mater Sci Mater Med 17: 63-67. Link: https://bit.ly/2waiTKQ

9. Metikos-Huković M, Kwokal A, Piljac J (2003) The influence of niobium and vanadium on passivity of titanium-based implants in physiological solution. Biomaterials 24: 3765-3775. Link: https://bit.ly/2WYCVTz

10. Wang YB, Zheng YF (2009) Corrosion behaviour and biocompatibility evaluation of low modulus $\mathrm{Ti}-16 \mathrm{Nb}$ shape memory alloy as potential biomaterial. Mater Lett. Elsevier B.V. 63: 1293-1295. Link: https://bit.ly/2JykjC4

11. Vilaplana J, Romaguera C (1998) New developments in jewellery and dental materials. Contact Dermatitis 39: 55-57. Link: https://bit.ly/342p4gx

12. do Prado RF, Rabêlo SB, de Andrade DP, Nascimento RD, Henriques VAR, et al. (2015) Porous titanium and Ti-35Nb alloy: effects on gene expression of osteoblastic cells derived from human alveolar bone. J Mater Sci Mater Med 26: 259. Link: https://bit.ly/2yst9Pn

13. do Prado RF, Esteves GC, Santos ELDS, Bueno DAG, Cairo CAA, et al. (2018) In vitro and in vivo biological performance of porous $\mathrm{Ti}$ alloys prepared by powder metallurgy. Egles C, editor. PLoS One 13: e0196169. Link: https://bit.ly/3dPZOyi

14. Costa BC, Tokuhara CK, Rocha LA, Oliveira RC, Lisboa-Filho PN, et al. (2019) Vanadium ionic species from degradation of Ti-6Al-4V metallic implants: In vitro cytotoxicity and speciation evaluation. Mater Sci Eng C Mater Biol App 96: 730-739. Link: https://bit.ly/2R33bll

15. Chandar S, Kotian R, Madhyastha P, Kabekkodu S, Rao P (2017) In vitro evaluation of cytotoxicity and corrosion behavior of commercially pure titanium and Ti-6Al-4V alloy for dental implants. J Indian Prosthodont Soc 17 35-40. Link: https://bit.ly/3aCSnZw

16. Corpa D, Tardelli J, Lima da Costa Valente $M$, Theodoro de Oliveira T, Cândido dos Reis A (2020) Influence of chemical composition on cell viability on titanium surfaces: A systematic review. J Prosthet Dent. Editorial Council for the Journal of Prosthetic Dentistry 1-5. Link: https://bit.ly/2UBxloE

17. Kim KT, Eo MY, Nguyen TTH, Kim SM (2019) General review of titanium toxicity. Int J Implant Dent. International Journal of Implant Dentistry 5. Link: https://bit.ly/3aF0qow

18. Wachesk CC, Trava-Airoldi VJ, Da-Silva NS, Lobo AO, Marciano FR (2016) The Influence of Titanium Dioxide on Diamond-Like Carbon Biocompatibility for Dental Applications. J Nanomater 2016: 1-7. Link: https://bit.ly/345Ed0I

19. Opačić-Galić V, Petrović V, Živković S, Jokanović V, Nikolić B, et al. (2013) New nanostructural biomaterials based on active silicate systems and hydroxyapatite: characterization and genotoxicity in human peripheral blood lymphocytes. Int Endod J 46: 506-516. Link: https://bit.ly/2X15Lmd

20. Gomes-Cornélio Al, Rodrigues Em, Mestieri Lb, Falcoski T De Ors, Soares Cp et al. (2016) Cytotoxicity and genotoxicity of calcium silicate-based cements on an osteoblast lineage. Braz Oral Res 30: 1-10. Link: https://bit.ly/3bHwRD0

21. Suzuki T, Miura N, Hojo R, Yanagiba Y, Suda M, et al. (2016) Genotoxicity assessment of intravenously injected titanium dioxide nanoparticles in gpt delta transgenic mice. Mutat Res Genet Toxicol Environ Mutagen 802: 30-37. Link: https://bit.ly/2JyQEZu

22. Tong L, Zhou W, Zhao Y, Yu X, Wang H, et al. (2016) Enhanced cytocompatibility and reduced genotoxicity of polydimethylsiloxane modified by plasma immersion ion implantation. Colloids Surfaces B Biointerfaces 148: 139-146. Link: https://bit.ly/2V1ikeS

23. Zhang N, Said A, Wischke C, Kral V, Brodwolf R, et al. (2017) Poly[acrylonitrile co -( $\mathrm{N}$-vinyl pyrrolidone)] nanoparticles-Composition-dependent skin penetration enhancement of a dye probe and biocompatibility. Eur J Pharm Biopharm 116: 66-75. Link: https://bit.ly/2X2mGVn

24. Zivkovic L, Akar B, Roux BM, Spremo Potparevic B, Bajic V, et al. (2017) Investigation of DNA damage in cells exposed to poly (lactic-co-glycolic

Citation: De Andrade DP, Silva Carvalho IC, Godoi BH, Da Silva NS, Soares CP, et al. (2020) In vitro genotoxic study reinforces the use of titanium-35niobium alloy in biomedical implants. Int J Oral Craniofac Sci 6(1): 008-015. DOI: https://dx.doi.org/10.17352/2455-4634.000044 
acid) microspheres. J Biomed Mater Res-Part A 105: 284-291. Link: https://bit.ly/3aBGmnf

25. Fairbairn DW, Olive PL, O'Neill KL (1995) The comet assay: a comprehensive review. Mutat Res 339: 37-59. Link: https://bit.ly/2UTZwOz

26. ISO/EN10993-5 (2009) Biological evaluation of medical devices-Part 5: Tests for in vitro cytotoxicity. Int Stand ISO 10993-5 Biol Eval Med devices-Part 5 Tests Cytotox Vitr methods 3: 42. Link: https://bit.ly/3dXSEZc

27. Carvalho ICS, Dutra TP, De Andrade DP, Balducci I, Pacheco-Soares C, et al. (2016) High doses of alcohol during pregnancy cause DNA damages in osteoblasts of newborns rats. Birth Defects Res Part A Clin Mol Teratol 106 122-132. Link:

28. Titenko-Holland N, Moore LE, Smith MT (1994) Measurement and characterization of micronuclei in exfoliated human cells by fluorescence in situ hybridization with a centromeric probe. Mutat Res 312: 39-50. Link: https://bit.ly/348s6zJ

29. ISO/EN10993-3 (2003) Biological evaluation of medical devices-Part 3: Tests for genotoxicity, carcinogenicity and reproductive toxicity. Int Organ Stand 10993-3 Biol Eval Med devices-Part 3 Tests genotoxicity, Carcinog Reprod Toxic. Geneva 2 Ed. Link: https://bit.ly/2Jx7DLt

30. Hartmann A (2003) Recommendations for conducting the in vivo alkaline Comet assay. Mutagenesis 18: 45-51. Link: https://bit.ly/3bNQiKz

31. Bhattacharya K, Davoren M, Boertz J, Schins RP, Hoffmann E, et al. (2009) Titanium dioxide nanoparticles induce oxidative stress and DNA-adduct formation but not DNA-breakage in human lung cells. Part Fibre Toxicol 6: 17 Link: https://bit.ly/2UCTgeQ

32. Petersen EJ, Nelson BC (2010) Mechanisms and measurements of nanomaterial-induced oxidative damage to DNA. Anal Bioanal Chem 398: 613650. Link: https://bit.ly/3axxY89

33. Karlsson HL (2010) The comet assay in nanotoxicology research. Anal Bioanal Chem 398: 651-666. Link: https://bit.ly/344IL8s

34. Technical Committee ISO/TC 229 (2013) Nanotechnologies-Compilation and description of toxicological screening methods for manufactured nanomaterials 2014. Link: https://bit.ly/2wVTK70

35. Collins AR (2004) The Comet Assay for DNA Damage and Repair: Principles, Applications, and Limitations. Mol Biotechnol 26: 249-261.

36. Collins AR, Oscoz AA, Brunborg G, Gaivao I, Giovannelli L, et al. (2008) The comet assay: Topical issues. Mutagenesis 23: 143-151. Link: https://bit.ly/3alsc30

37. Braafladt S, Reipa V, Atha DH (2016) https://go.nature.com/2UC5q7P Link:

38. Glei M, Schneider T, Schlörmann W (2016) Comet assay: An essential too in toxicological research. Arch Toxicol. Springer Berlin Heidelberg 90: 2315 2336. Link: https://bit.ly/3bHHR3h

39. Grover P, Danadevi K, Mahboob M, Rozati R, Banu BS, et al. (2003) Evaluation of genetic damage in workers employed in pesticide production utilizing the Comet assay. Mutagenesis 18: 201-205. Link: https://bit.ly/3bVWPD5

40. Singh NP, McCoy MT, Tice RR, Schneider EL (1988) A simple technique for quantitation of low levels of DNA damage in individual cells. Exp Cell Res 175 : 184-191. Link: https://bit.ly/3aDaHBO

41. Moro AM, Brucker N, Charão M, Bulcão R, Freitas F, et al. (2012) Evaluation of genotoxicity and oxidative damage in painters exposed to low levels of toluene. Mutat Res Toxicol Environ Mutagen 746: 42-48. Link: https://bit.ly/2xFFUpi

42. Dhawan A, Bajpayee M, Parmar D (2009) Comet assay: A reliable tool for the assessment of DNA damage in different models. Cell Biol Toxicol 25: 5-32. Link: https://bit.ly/2R4eDnk
43. Gyori BM, Venkatachalam G, Thiagarajan PS, Hsu D, Clement M-V (2014) OpenComet: An automated tool for comet assay image analysis. Redox Biol. Elsevier 2: 457-465. Link: https://bit.ly/3bOHIAF

44. Weng X, Yang H, Xu J, Li X, Liao Q, et al. (2016) In vivo testing of porous Ti$25 \mathrm{Nb}$ alloy serving as a femoral stem prosthesis in a rabbit model. Exp Ther Med 12: 1323-1330. Link: https://bit.ly/2R5wkTp

45. Brentel AS, Vasconcellos LMR de, Oliveira MV, Graça ML de A, Vasconcellos LGO de, et al. (2006) Histomorphometric analysis of pure titanium implants with porous surface versus rough surface. J Appl Oral Sci 14: 213-218. Link: https://bit.ly/2wVVehA

46. Fenech M, Nersesyan A, Knasmueller S (2016) A systematic review of the association between occupational exposure to formaldehyde and effects on chromosomal DNA damage measured using the cytokinesisblock micronucleus assay in lymphocytes. Mutat Res 770: 46-57. Link: https://bit.ly/3bFQk6U

47. Thomas P, Fenech M (2011) Cytokinesis-Block Micronucleus Cytome Assay in Lymphocytes. In: Methods in Molecular Biology 217-234. Link: https://bit.ly/2JKenWJ

48. Tolbert PE, Shy CM, Allen JW (1992) Micronuclei and other nuclear anomalies in buccal smears: methods development. Mutat Res Mutagen Relat Subj 271 69-77. Link: https://bit.ly/3dHayiy

49. Tian $Y$, Shen $L$, Gao $Y$, Yamauchi $T$, Shen $X$, et al (2007) Comparison of 4', 6'-diamidino-2-phenylindole and Giemsa Stainings in Preimplantation Mouse Embryos Micronucleus Assay Including a Triple Dose Study. Ind Health 45 343-347. Link: https://bit.ly/2X3tJ0k

50. Kotova N, Vare D, Schultz N, Meesters DG, Stepnik M, et al. (2013) Genotoxicity of alcohol is linked to DNA replication-associated damage and homologous recombination repair. Carcinogenesis 34: 325-330. Link: https://bit.ly/2XOyYOE

51. Ko H, Jeong Y, Kim M (2017) Cytotoxicities and genotoxicities of cements based on calcium silicate and of dental formocresol. Mutat Res Toxicol Environ Mutagen 815: 28-34. Link: https://bit.ly/2WXVdEu

52. Reis É de M, Rezende AAA de, Oliveira PF de, Nicolella HD, Tavares DC, et al. (2016) Evaluation of titanium dioxide nanocrystal-induced genotoxicity by the cytokinesis-block micronucleus assay and the Drosophila wing spot test Food Chem Toxicol 96: 309-319. Link: https://bit.ly/3axzLtT

53. Rocco L, Santonastaso M, Nigro M, Mottola F, Costagliola D, et al. (2015) Genomic and chromosomal damage in the marine mussel Mytilus galloprovincialis: Effects of the combined exposure to titanium dioxide nanoparticles and cadmium chloride. Mar Environ Res 111: 144-148. Link: https://bit.ly/2X2VxBG

54. Shakeel M, Jabeen F, Qureshi NA, Fakhr-e-Alam M (2016) Toxic Effects of Titanium Dioxide Nanoparticles and Titanium Dioxide Bulk Salt in the Live and Blood of Male Sprague-Dawley Rats Assessed by Different Assays. Biol Trace Elem Res 173: 405-426. Link: https://bit.ly/3bHLndW

55. Dobrzyńska MM, Gajowik A, Radzikowska J, Lankoff A, Dušinská M, et al (2014). Genotoxicity of silver and titanium dioxide nanoparticles in bone marrow cells of rats in vivo. Toxicology 315: 86-91. Link: https://bit.ly/2yknhYf

56. Tavares AM, Louro H, Antunes S, Quarré S, Simar S, et al. (2014) Genotoxicity evaluation of nanosized titanium dioxide, synthetic amorphous silica and multi-walled carbon nanotubes in human lymphocytes. Toxicol Vitr 28: 60-69. Link: https://bit.ly/2w7u0El v

57. Karahalil B, Kadioglu E, Tuzuner-Oncul AM, Cimen E, Emerce E, et al. (2014) Micronucleus assay assessment of possible genotoxic effects in patients treated with titanium alloy endosseous implants or miniplates. Mutat Res Genet Toxicol Environ Mutagen 760: 70-72. Link: https://bit.ly/2UCmoTE

58. Cooper GM (2000) The Cell: A Molecular Approach. 2. 9876. Link: https://amzn.to/3bCuSQq

Citation: De Andrade DP, Silva Carvalho IC, Godoi BH, Da Silva NS, Soares CP, et al. (2020) In vitro genotoxic study reinforces the use of titanium-35niobium alloy in biomedical implants. Int J Oral Craniofac Sci 6(1): 008-015. DOI: https://dx.doi.org/10.17352/2455-4634.000044 
59. Geng Z, Yuan Q, Zhuo X, Li Z, Cui Z, et al. (2017) Synthesis, Characterization, and Biological Evaluation of Nanostructured Hydroxyapatite with Different Dimensions. Nanomaterials 7: 38. Link: https://bit.ly/2xMYJqv

60. Shen D, Horiuchi N, Nozaki S, Miyashin M, Yamashita K, et al. (2017) Synthesis and enhanced bone regeneration of carbonate substituted octacalcium phosphate. Yamashita K, Okazaki M, editors. Biomed Mater Eng 28: 9-21. Link: https://bit.ly/34fdr69

61. Zhang J, Sun L, Luo X, Barbieri D, de Bruijn JD, et al. (2017) Cells responding to surface structure of calcium phosphate ceramics for bone regeneration. $J$ Tissue Eng Regen Med 11: 3273-3283. Link: https://bit.ly/39x5fil

Discover a bigger Impact and Visibility of your article publication with Peertechz Publications

\section{Highlights}

* Signatory publisher of ORCID

* Signatory Publisher of DORA (San Francisco Declaration on Research Assessment)

* Articles archived in worlds' renowned service providers such as Portico, CNKI, AGRIS, TDNet, Base (Bielefeld University Library), CrossRef, Scilit, J-Gate etc.

- Journals indexed in ICMJE, SHERPA/ROMEO, Google Scholar etc.

* OAI-PMH (Open Archives Initiative Protocol for Metadata Harvesting)

* Dedicated Editorial Board for every journal

* Accurate and rapid peer-review process

* Increased citations of published articles through promotions

* Reduced timeline for article publication

Submit your articles and experience a new surge in publication services (https://www.peertechz.com/submission).

Peertechz journals wishes everlasting success in your every endeavours.

Copyright: @ 2020 De Andrade DP, et al. This is an open-access article distributed under the terms of the Creative Commons Attribution License, which permits unrestricted use, distribution, and reproduction in any medium, provided the original author and source are credited.

Citation: De Andrade DP, Silva Carvalho IC, Godoi BH, Da Silva NS, Soares CP, et al. (2020) In vitro genotoxic study reinforces the use of titanium-35niobium alloy in biomedical implants. Int J Oral Craniofac Sci 6(1): 008-015. DOI: https://dx.doi.org/10.17352/2455-4634.000044 